infection, causing an immunological response. These were a high incidence of anticomplementary activity in sera, with higher levels in the first paired sera, from individual patients and from the results of electronmicroscopy showing "complexes" in the serum. It is now established that anticomplementary activity is a simple test showing the presence of immune complexes in the serum. In fact, the presence of anticomplementary activity was the first suggestion that immune complexes could be present in the circulation with Australia antigen (Shulman and Barker, 1969).

Lymphocyte cultures was decided on because of the relative ease with which lymphocytes from conditions such as certain lymphoproliferative disorders and infectious mononucleosis proliferate in vitro. Though this is possible in some normal people massive numbers of lymphocytes are required. In the present study only 4 and $20 \times 10^{6}$ lymphocytes were used in separate cultures and yet in one of the sets of cultures proliferation readily occurred, permitting subcultures to be made in which proliferation continued. The usefulness of this investigation was limited by the disappointing loss of the cultures through a technical mishap at a relatively early stage. Some of the proliferating lymphocytes had, however, been examined by electronmicroscopy without providing any positive information.

This report of the syndrome of epidemic neuromyasthenia adds to the literature on a puzzling condition, since its aetiology remains unknown. Though it seems to be somewhat uncommon the attack rate in communities in which it has been described is high. Perhaps it is uncommon because the broad spectrum of the relatively mild symptoms may not be readily recognizable in the general community, whereas in relatively restricted populations departures from communal norms are more easily recognized (Graybill et al., 1972). We have used the term "epidemic neuromyasthenia" for this unexplained illness for the same reasons as Henderson and Shelokov (1959). It resembles in many ways outbreaks they have studied (Shelokov et al., 1957). This term seems to be the least objectionable in the limits of our present understanding. Acheson (1959), however, thinks that "benign myalgic encephalomyelitis" is more suitable. Both terms would seem to be acceptable but clearly they are not entirely satisfactory.

We would like to thank Dr. Marguerite Pereira of the Central Public Health Laboratory, Colindale, Middlesex, for assistance with the virological studies; Dr. June Almeida of the Royal Postgraduate Medical School, Hammersmith Hospital, London, for her advice and criticism, in addition to electronmicroscopic studies; and Mr. G. T. Hawkins, F.I.M.L.T., for valuable technical assistance in the laboratory investigations.

\section{References}

Acheson, E. D. (1959). American fournal of Medicine, 26, 569. Almeida, June D., and Waterson, A. P. (1969). Advances in Virus Research, $15,307$.

British Medical fournal, 1957, 2, 927.

Geffen, D., and Tracy, S. M. (1957). British Medical fournal, 2, 904 Geffen, D., and Tracy, S. M. (1957). British Medical fournal, 2, 904.

Graybill, J. R., Silva, J., O'Brien, M. S., and Reinerz, J. A. (1972). Fournal of the American Medical Association, 219, 1440.

Henderson, D. A., and Shelokov, A. (1959). New England fournal of Medicine, 260, 757 and 814

Hill R. C. J. (1955). South African Medical fournal, 29, 544.

Innes, S. G. B. (1970). Lancet, 1, 969

Jackson, A. L. (1957). South African Medical fournal, 31, 514.

Lancet, 1956, 1, 789 .

McEvedy, C. P., and Beard, A. W. (1970 a). British Medical fournal, 1, 7 McEvedy, C. P., and Beard, A. W. (1970 b). British Medical Fournal, 1, 11 Miller, G., Chamberlain, R., and McCormick, W. M. (1967). American Fournal of Epidemiology, 86, 756.

Royal Free Hospital Staff (1957), British Medical fournal, 2, 895.

Schuler, E. A., and Parenton, V. J. (1943). Fournal of Social Psychology, 17,

221.
Shelokov, A. (1972). In Infectious Diseases, ed. P. D. Hoeprich, p. 1297. Maryland, Harper and Rowe.

Maryland, Harper and Rowe.
Shelokov, A., Habel, K., Verdor, E., and Welsh, W. (1957). New England fournal of Medicine, 257, 345 .

Shulman, N. R., and Barker, L. F. (1969). Science, 165, 304.

Sigurdsson, B., and Gudmundsson, K. R. (1956). Lancet, 1, 766.

Steigman, A. J. (1951). Special Report to the National Foundation of Infantile Paralysis, Inc., New York.

White, D. N., and Burtch, R. B. (1954). Neurology, 4, 506.

\title{
Medicines Evaluation and Monitoring Group: Central Nervous System Effects of Pentazocine
}

\author{
A. J. J. WOOD, \\ S. MCALLION \\ C. CAMPBELL, J. F. DAVIDSON, \\ S. C. GALLON, \\ E. HENNEY, \\ D. C. MOIR,
}

British Medical fournal, 1974, 1, 305-307

\section{Summary}

Hospital-based drug monitoring facilities have been used to investigate the frequency of perceptual disturbances in inpatients receiving pentazocine and the occurrence of dependence upon this drug after discharge from hospital. A pilot

Dundee University, Dundee DD1 4HN

A. J. J. WOOD, M.B., CH.B., Registrar, Department of Pharmacology and Therapeutics

C. CAMPBELL, Medical Student

S. McAlliON, Medical Student

Department of Social Medicine, Aberdeen University, Aberdeen AB9 1AS

D. C. MOIR, M.D., Lecturer

J. F. DAVIDSON, M.B., CH.B., Research Assistant

S. C. GALLON, M.B., CH.B., Research Assistant

Maryfield Hospital, Dundee

E. HENNEY, R.G.N., S.C.M., Research Sister study was carried out in which seven out of 70 hospital inpatients receiving pentazocine reported such episodes, while in a prospective study, 9 out of 132 patients receiving pentazocine and 1 out of 112 receiving cyclimorph, dihydrocodeine, or pethidine reported their occurrence. A total of 135 patients who received pentazocine for disorders likely to require longterm analgesia were followed up for six months after their discharge from hospital. 24 had received pentazocine after discharge; two required an increase in dosage and four expressed a preference for pentazocine.

\section{Introduction}

Since the introduction of pentazocine in 1967 bizarre central nervous system disturbances such as hallucinations, euphoria, and feelings of depersonalization have been reported following its administration (De Nosaquo, 1970; Edison, 1969) and the occurrence of dependence has also been recorded (Hart, 1969; Mungavin, 1969; Sandoval and Wang, 1969; Scholar et al., 1969). An investigation was conducted to estimate the frequency with which hospital inpatients receiving pentazocine 
reported perceptual disturbances (visual, auditory, etc.) which were independent of the appropriate stimuli, and, while it was not possible to match these patients accurately, those receiving analgesics such as dihydrocodeine or methadone were interviewed to determine the frequency of hallucinatory episodes in similar populations. A follow-up study to ascertain whether patients given pentazocine in hospital had become dependent on the drug was also undertaken.

\section{Methods}

Pilot Study.-Patients receiving oral or intramuscular pentazocine, dihydrocodeine, or methadone were identified by means of a drug prescribing system (Crooks et al., 1965) and were interviewed, using a standard questionnaire, within 36 hours of the last dose concerning the occurrence of various symptoms including unusual psychological phenomena. The opportunity was taken to ask "open-ended" questions which allowed the patient some latitude to talk about recent symptoms.

Prospective Study.-Patients who had received pentazocine, cyclimorph, dihydrocodeine, or pethidine in the preceding 24 hours were selected as before, but by one investigator. The other investigator undertook the interviews but, to eliminate possible bias, did not know which drugs the patients had had.

Follow-up Study.-Patients who had received pentazocine in hospital over a period of six months were identified by means of a drug information system (Coull et al., 1970). Three groups of patients with conditions likely to require long-term analgesia were selected and questionnaires were sent to their general practitioners about their analgesic medication.

\section{Results}

Pilot Study.-Of 103 patients interviewed 70 had received pentazocine, 28 dihydrocodeine, and 5 methadone. Of the 70 receiving pentazocine seven $(10 \%)$ experienced perceptual disturbances, two after intramuscular and five after oral administration, and one of the patients receiving dihydrocodeine orally experienced such a disturbance (table I). Patients who admitted to abnormal perceptions but described them as "dreams" were excluded.

Prospective Study.-Of the 244 patients interviewed 132 had received pentazocine, 55 cyclimorph, 30 dihydrocodeine, and 27 pethidine. Nine of the 132 experienced perceptual disturb- ances, six after intramuscular and three after oral administration of petazocine, while only one of the remaining 112 patients, who had received another analgesic, experienced similar episodes (table II).

Follow-up Study.-Fifty neurosurgical, 39 orthopaedic, and 46 cancer patients were identified and 129 replies were received to the questionnaires sent to their general practitioners. Only 24 patients had received pentazocine after discharge, and two of them had required an increase in dosage. Fifty-one patients had received other analgesic medication and six expressed a preference for a particular drug. Four of the 24 patients receiving pentazocine expressed a preference for it.

\section{Discussion and Conclusions}

In a social climate in which hallucinogens are increasingly used it is important to establish the frequency with which such effects are produced. An attempt was therefore made to determine the occurrence of unusual psychological phenomena in hospital inpatients, using the drug monitoring facilities of the Aberdeen and Dundee hospitals. While 18 cases of perceptual disturbance were detected by the monitoring team (tables I and II), only one of these was spontaneously reported by a hospital dootor to the Committee on Safety of Medicines. Preexisting monitoring facilities for investigating and assessing the clinical significance of suspected adverse drug reactions as soon as they occur are therefore of considerable importance. In the present study we achieved a result within a period of six weeks.

Though the study supported the association of pentazocine with perceptual disturbances, and showed the incidence to be between $7 \%$ and $10 \%$, the patients received the drug in normal therapeutic doses. It would therefore be uniustified to assume that the incidence would be the same if a higher dosage were taken. It is of interest to note that the disturbances occurred as often after oral as after intramuscular administration of the drug.

In general, visual disturbances were more common than auditory, though some patients experienced both simultaneously. There was also a wide spectrum of reactions from those of pleasure to those of intense dislike. Pentazocine is commonly prescribed for outpatients $(569,000$ prescriptions in 1970), and even if only $7 \%$ of them experience hallucinations these will probably soon occur in a patient who has already abused other drugs for their psychotropic effects. Our preliminary investigation of outpatients who had received pentazocine in hospital provided little evidence that the patients had become habitu-

TABle I-Pilot Study: Histories of Eight Patients who experienced Perceptual Disturbances after the Administration of Analgesics

\begin{tabular}{|c|c|c|c|c|c|c|}
\hline Age & Sex & Diagnosis & Pentazocine Dosage & $\begin{array}{l}\text { Dihydrocodeine } \\
\text { tartrate Dosage }\end{array}$ & Concurrent Drug Therapy & $\begin{array}{l}\text { Patients' Descriptions of } \\
\text { Perceptual Disturbances }\end{array}$ \\
\hline 57 & M. & $\begin{array}{l}\text { Hypertension; } \\
\text { malignant melanoma } \\
\text { of eye }\end{array}$ & $\begin{array}{l}50 \mathrm{mg} \text { orally } \\
4 \text { hourly }\end{array}$ & - & $\begin{array}{l}\text { Acetazolamide, betamethazone } \\
\text { eye-drops, triclofos sodium }\end{array}$ & $\begin{array}{l}\text { Thought ceiling had a zig-zag pattern. } \\
\text { Felt he was being watched all the time. }\end{array}$ \\
\hline 35 & M. & $\begin{array}{l}\text { Fracture of left } \\
\text { tibia and fibula }\end{array}$ & $\begin{array}{l}60 \mathrm{mg} \text { i.m. } \times 2 \\
50 \mathrm{mg} \text { orally } \\
6 \text { hourly }\end{array}$ & - & Nitrazepam & $\begin{array}{l}\text { Felt legs were floating and buttocks were } \\
\text { rotating "like helicopter blades." Felt foot } \\
\text { was hinged at the toes with his heel } \\
\text { flapping free. }\end{array}$ \\
\hline 75 & F. & Thyrotoxicosis & $\begin{array}{l}30 \mathrm{mg} \text { orally } \\
6 \text { hourly }\end{array}$ & - & $\begin{array}{l}\text { Amylobarbitone, } \\
\text { paracetamol }\end{array}$ & $\begin{array}{l}\text { Saw mice and grass snakes crawling over } \\
\text { next bed and subsequently coming onto } \\
\text { her bed. }\end{array}$ \\
\hline 18 & M. & Perineal abscess & $30 \mathrm{mg}$ i.m. $\times 1$ & - & $\begin{array}{l}\text { Ascorbic acid, diazepam, } \\
\text { paracetamol, zinc sulphate }\end{array}$ & $\begin{array}{l}\text { Heard exaggerated noises-watch sounded } \\
\text { like Big Ben. Thought other patients } \\
\text { were screaming. }\end{array}$ \\
\hline 59 & M. & $\begin{array}{l}\text { Acute prolapsed } \\
\text { intravertebral disc }\end{array}$ & $\begin{array}{l}60 \mathrm{mg} \text { i.m. } \\
8 \text { hourly }\end{array}$ & - & $\begin{array}{l}\text { Diazepam, Distalgesic, } \\
\text { cyclopenthiazide, nitrazepam }\end{array}$ & $\begin{array}{l}\text { Felt he was floating on air, and that the } \\
\text { bed moved. Saw walls as pink and yellow } \\
\text { curtains opening and closing. }\end{array}$ \\
\hline 45 & M. & $\begin{array}{l}\text { Myocardial } \\
\text { infarction }\end{array}$ & $100 \mathrm{mg}$ orally $\times 2$ & - & $\begin{array}{l}\text { Allopurinol, nitrazepam, } \\
\text { phenylbutazone }\end{array}$ & $\begin{array}{l}\text { Felt he was floating on a pink cloud. } \\
\text { Aware of watch ticking very loudly. }\end{array}$ \\
\hline 50 & M. & Sarcoidosis & $\begin{array}{l}50 \mathrm{mg} \text { orally } \\
4 \text { hourly }\end{array}$ & - & $\begin{array}{l}\text { Folic acid, Orovite, } \\
\text { prednisolone }\end{array}$ & Thought he was in a caravan. \\
\hline 51 & M. & $\begin{array}{l}\text { Osteomyelitis of } \\
\text { right clavicle }\end{array}$ & - & $\begin{array}{l}60 \mathrm{mg} \text { orally } \\
6 \text { hourly }\end{array}$ & $\begin{array}{l}\text { Benzylpenicillin, } \\
\text { clindamycin }\end{array}$ & $\begin{array}{l}\text { Felt that everything was in the wrong } \\
\text { place. Felt as if he were up on the ceiling } \\
\text { and that he was the king looking down } \\
\text { on everyone else. }\end{array}$ \\
\hline
\end{tabular}


TABle II-Prospective Study: Histories of 10 Patients who experienced Perceptual Disturbances after the Administration of Analgesics

\begin{tabular}{|c|c|c|c|c|c|c|}
\hline Age & Sex & Diagnosis & Pentazocine Dosage & $\begin{array}{c}\text { Morphine Tartrate/ } \\
\text { Cyclizine Tartrate Dosage }\end{array}$ & Concurrent Drug Therapy & $\begin{array}{l}\text { Patients' Descriptions of } \\
\text { Perceptual Disturbances }\end{array}$ \\
\hline 22 & F. & $\begin{array}{l}\text { Urinary tract } \\
\text { infection }\end{array}$ & $30 \mathrm{mg}$ i.m. $\times 1$ & - & Nitrazepam, nitrofurantoin & $\begin{array}{l}\text { Saw goldfish and aeroplanes rising out of } \\
\text { cracks in the floor. }\end{array}$ \\
\hline 25 & F. & Headache & $30 \mathrm{mg}$ i.m. $\times 1$ & - & - & $\begin{array}{l}\text { Saw tigers advancing and retreating from a } \\
\text { semi-circle at the end of her bed. Saw a } \\
\text { court of law with no one in the dock and } \\
\text { subsequently various people she knew } \\
\text { appeared vividly. }\end{array}$ \\
\hline 48 & F. & Acute cholecystitis & $50 \mathrm{mg}$ i.m. & - & Crystamycin prochlorperazine & $\begin{array}{l}\text { Heard strange noises accompanied by } \\
\text { vertigo. }\end{array}$ \\
\hline 47 & F. & $\begin{array}{l}\text { Carcinoma of the } \\
\text { breast }\end{array}$ & $50 \mathrm{mg}$ orally & - & Nitrazepam & Felt a floating, rocking sensation. \\
\hline 59 & M. & Amputation & $50 \mathrm{mg}$ orally & - & $\begin{array}{l}\text { Ampicillin, cloxacillin, } \\
\text { frusemide, potassium chloride }\end{array}$ & Felt the roof was falling in on top of him. \\
\hline 53 & M. & $\begin{array}{l}\text { Carcinoma of the } \\
\text { stomach }\end{array}$ & $90 \mathrm{mg}$ i.m. & - & - & $\begin{array}{l}\text { Saw people and pink shapes running } \\
\text { up and down the ward. }\end{array}$ \\
\hline 52 & F. & Prolapsed cystocele & $60 \mathrm{mg}$ i.m. & - & Ampicillin, diazepam & $\begin{array}{l}\text { Saw her son who was known by her to be } \\
\text { several hundreds of miles away coming to } \\
\text { visit her. }\end{array}$ \\
\hline 74 & F. & Gangrenous toe & $50 \mathrm{mg}$ orally & - & Cephalexin & $\begin{array}{l}\text { Described a fearful period when she was } \\
\text { able to see strange things like red devils. }\end{array}$ \\
\hline 71 & F. & $\begin{array}{l}\text { Ischaemic heart } \\
\text { disease }\end{array}$ & $30 \mathrm{mg}$ i.m. & - & - & $\begin{array}{l}\text { Saw and talked to people round the end } \\
\text { of her bed who were not there. }\end{array}$ \\
\hline 63 & M. & Perforated peptic ulcer & - & $7.5 \mathrm{mg}$ i.m. & Tetracycline & $\begin{array}{l}\text { Saw people at the end of his bed who were } \\
\text { not there. }\end{array}$ \\
\hline
\end{tabular}

ated to the drug, and apparently it was not associated with dependence in any appreciable number of patients.

This work was assisted by research grants from the Department of Health and Social Security, the Scottish Home and Health Department and the World Health Organization. We would like to thank Professor J. Crooks and Professor R. D. Weir for advice, and the medical staff of the Aberdeen and Dundee Hospitals and the general practitioners in the North-east of Scotland for their co-operation.

\section{References}

Coull, D. C., Crooks, J., Davidson, J. F., Gallon, S. C., and Weir, R. D. (1970). European fournal of Clinical Pharmacology, 3, 46.

Crooks, J.; Clark, C. G., Caie, H. B., and Mawson, W. B. (1965). Lancet, $1,373$.

De Nosaquo, N. (1969). Journal of American Medical Association, 210, 502.

Edison, G. R. (1969). New England fournal of Medicine, 281, 447.

Hart, R. H. (1969). Lancet, 2, 690.

Mungavin, J. M. (1969). Lancet, $2,56$.

Sandoval, R. G., and Wang, R. I. H. (1969). New England fournal of Medicine, 280,1391 .

Scolar, J. C., Idanpaan-Heikkila, P., and Keats, A. S. (1969). Lancet, 1,32

\title{
Respiratory Intensive Care: A Io-Year Survey
}

\author{
R. K. B. YOUNG, \\ D. CAMPBELL, J. M. REID, \\ A. B. M. TELFER
}

British Medical fournal, 1974, 1, 307-310

\section{Introduction}

\section{Summary}

The work of the respiratory intensive care unit at the Glasgow Royal Infirmary covering a period of 10 years and involving more than 2,000 patients has been analysed. The rate of admission of patients with acute respiratory or metabolic disturbances remained surprisingly constant over the years, allowing for the increase in available beds after 1965. A disturbing feature was the notable increase in the incidence of severe self-poisonings. The continued importance of infection as a life-threatening complication is also emphasized. The reduction in mortality observed in some of the most gravely ill patients appears to justify this approach to patient care.

Some years ago the report of the B.M.A.'s Working Party on Intensive Care was published. ${ }^{1}$ The survey was based on a study of 15 representative intensive care units throughout the United Kingdom in both teaching and district hospitals. Commenting on the information derived from the survey the authors underlined the need at that time for more details on the nature of the work done in the various units, the pattern of admission, staffing, and methods of management. As a result of this we produced a report based on four years' experience of respiratory intensive care in a large teaching hospital in an industrial environment. 2 Some six years later it seemed worth while to re-examine the pattern of admissions to the eight-bed respiratory intensive care unit at the Glasgow Royal Infirmary to see if there had been any significant changes in the pattern of admissions, the incidence of certain conditions, and morbidity. The results are reported here.

\section{Results}

The Glasgow Royal Infirmary is a major teaching hospital with a large emergency commitment for both medical and surgical 